\title{
Colonization potential of the genus Ulva (Chlorophyta, Ulvales) in Comodoro Rivadavia Harbor (Chubut, Argentina)
}

\section{El potencial de colonización del género Ulva (Chlorophyta, Ulvales) en el puerto de Comodoro Rivadavia (Chubut, Argentina)}

\author{
Alicia Rico ${ }^{1 *}$ \\ Paola Lanas ${ }^{1}$ \\ Juan López-Gappa ${ }^{2}$ \\ ${ }^{1}$ Departamento de Biología General \\ Facultad de Ciencias Naturales \\ Universidad Nacional de la Patagonia \\ Ciudad Universitaria, $\mathrm{Km} 4$ \\ 9000 Comodoro Rivadavia, Chubut, Argentina \\ *E-mail: arico@unpata.edu.ar \\ ${ }^{2}$ Museo Argentino de Ciencias Naturales \\ Angel Gallardo 470 \\ C1405DJR Buenos Aires, Argentina \\ E-mail: lgappa@mail.retina.ar
}

Recibido en julio de 2004; aceptado en junio de 2005

\begin{abstract}
Temporal and spatial changes in the coverage of five Ulva L. species (U. prolifera O.F. Müller, U. intestinalis L., U. hookeriana (Kützing) Hayden et al., U. compressa L. and $U$. linza L.) were analyzed on rocky substrata experimentally immersed in Comodoro Rivadavia Harbor (Argentina). Colonization was studied during an annual period at three levels: upper intertidal, middle intertidal and subtidal. Coverage was significantly higher in the middle intertidal and subtidal levels than in the upper intertidal level, where all species of Ulva were absent. Seasonal changes were also significant: coverage in summer and spring was significantly higher than in autumn and winter. Most species showed high spatial variability among replicates from the same level and season. Zonation patterns within the harbor differed from those observed in natural areas, probably due to low wave exposure and its interaction with herbivory and desiccation stress. Colonization patterns observed in this study indicate niche segregation in closely related species of the genus Ulva.
\end{abstract}

Key words: Ulva, Chlorophyta, Comodoro Rivadavia Harbor, Patagonia, Argentina.

\section{Resumen}

Se analizaron los cambios estacionales y espaciales en la cobertura de cinco especies de Ulva L. (U. prolifera O.F. Müller, U. intestinalis L., U. hookeriana (Kützing) Hayden et al., U. compressa L. y U. linza L.) sobre sustratos rocosos sumergidos experimentalmente en el puerto de Comodoro Rivadavia (Argentina). Se estudió la colonización durante un periodo anual en tres niveles: intermareal superior, intermareal medio y submareal. La cobertura fue significativamente mayor en los niveles intermareal medio y submareal que en el intermareal superior, en donde todas las especies de Ulva estuvieron ausentes. Los cambios estacionales también fueron significativos: la cobertura en verano y primavera fue significativamente mayor que en otoño e invierno. La mayoría de las especies presentaron una gran variabilidad espacial entre réplicas sumergidas en un mismo nivel y estación. Los patrones de zonación dentro del puerto difirieron de los observados en áreas naturales, probablemente a causa del bajo grado de exposición al oleaje y su interacción con procesos de herbivoría y desecación. Los patrones de colonización observados en este estudio indican segregación de nicho en especies estrechamente emparentadas del género Ulva.

Palabras clave: Ulva, Chlorophyta, puerto de Comodoro Rivadavia, Patagonia, Argentina. 


\section{Introduction}

Green macroalgae of the genus Ulva L. (including Enteromorpha Link) are widely distributed throughout the world (Hayden et al., 2003), sometimes forming dense algal mats in eutrophicated coastal areas and estuaries (Dolbeth et al., 2003; Cardoso et al., 2004; Cummins et al., 2004).

A recent revision based on molecular data concluded that the genera Enteromorpha and Ulva are not distinct evolutionary entities. Since the latter is the older name, Enteromorpha should be regarded as a synonym of Ulva (Hayden et al., 2003).

In Patagonia (Argentina), Rico et al. (1993) recorded six Ulva species for the Comodoro Rivadavia area: $U$. intestinalis L., U. compressa L., U. linza L., U. prolifera O.F. Müller, U. flexuosa Wulfen and $U$. hookeriana (Kützing) Hayden et al. [formerly E. bulbosa (Suhr) Montagne].

The genus Ulva is one of the most important members of fouling communities in harbors because of its strong resistance to toxic chemicals frequently employed in antifouling paints (Rascio and Bastida, 1973) and its high growth rate at salinities higher than 10 psu (Martins et al., 1999). Since the increase of green macroalgae may enhance sediment deposition (Romano et al., 2003) and significantly alter the structure of macrobenthic assemblages (Cardoso et al., 2004; Cummins et al., 2004), the aim of the present study was to analyze spatial and temporal changes in the coverage of the Ulva species colonizing experimental substrata immersed at different levels in Comodoro Rivadavia Harbor.

\section{Materials and methods}

\section{Study area}

Comodoro Rivadavia Harbor is located at $45^{\circ} 52^{\prime} \mathrm{S}$ and $67^{\circ} 28^{\prime}$ W (fig. 1). It is composed of two structures: an older section of vertical walls, and a new breakwater that was built using natural rocks and man-made concrete blocks. Tidal amplitude during spring and neap tides is 6.21 and $4.34 \mathrm{~m}$, respectively (Servicio de Hidrografía Naval, 1998). Salinity varies between 33.4 and 33.8 psu. Mean monthly temperatures of coastal waters near Comodoro Rivadavia vary between $9^{\circ} \mathrm{C}$ (August-September) and $16^{\circ} \mathrm{C}$ (February-March) (W. Maza, Climate Prediction Center, pers. comm.).

\section{Sampling and data analysis}

All sampling units consisted of the same granitic stones used to build the breakwater. They were originally extracted

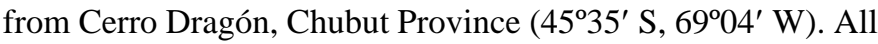
the experimental substrata used in this study were devoid of marine life since they had not been submerged. At the beginning of each season, roughly square-shaped stones ( $\mathrm{ca}$. $20 \times$ $20 \mathrm{~cm}$ ) were collected from the breakwater and glued to the

\section{Introducción}

Las algas verdes del género Ulva L. (incluyendo a Enteromorpha Link) están ampliamente distribuidas en todo el mundo (Hayden et al., 2003), a veces formando densas matas en estuarios y zonas costeras eutroficadas (Dolbeth et al., 2003; Cardoso et al., 2004; Cummins et al., 2004).

Una revisión reciente basada en datos moleculares concluyó que los géneros Enteromorpha Link y Ulva L. no son entidades evolutivas separadas. Dado que este último es el nombre más antiguo, Enteromorpha debe ser considerada sinónimo de Ulva (Hayden et al., 2003).

En Patagonia (Argentina), Rico et al. (1993) registraron la presencia de seis especies de Ulva para la zona de Comodoro Rivadavia: U. intestinalis L., U. compressa L., U. linza L., $U$. prolifera O.F. Müller, U. flexuosa Wulfen y U. hookeriana (Kützing) Hayden et al. [antes E. bulbosa (Suhr) Montagne].

El género Ulva es uno de los miembros más importantes de las incrustaciones biológicas en puertos debido a su gran resistencia a los tóxicos utilizados con frecuencia en las pinturas antiincrustantes (Rascio y Bastida, 1973) y a su alta tasa de crecimiento en salinidades mayores a 10 ups (Martins et al., 2003). Ya que el incremento de algas verdes puede aumentar la tasa de sedimentación (Romano et al., 2003) y alterar significativamente la estructura de las asociaciones macrobentónicas (Cardoso et al., 2004; Cummins et al., 2004), el propósito del presente trabajo fue analizar los cambios espaciales y temporales en la cobertura de las especies de Ulva que colonizaron sustratos experimentales sumergidos a distintos niveles en el puerto de Comodoro Rivadavia.

\section{Materiales y métodos}

Área de estudio

El puerto de Comodoro Rivadavia se encuentra ubicado en $45^{\circ} 52^{\prime} \mathrm{S}$ y $67^{\circ} 28^{\prime} \mathrm{W}$ (fig. 1). Está compuesto por dos estructuras, una más antigua de paredes verticales y una nueva escollera construida con rocas naturales y bloques artificiales de cemento. La amplitud durante las mareas de sicigias y cuadraturas es de 6.21 y $4.34 \mathrm{~m}$, respectivamente (Servicio de Hidrografía Naval, 1998). La salinidad varía entre 33.4 y 33.8 ups. Las temperaturas medias mensuales del agua costera cerca de Comodoro Rivadavia varían entre $9^{\circ} \mathrm{C}$ (agosto-septiembre) y $16^{\circ} \mathrm{C}$ (febrero-marzo) (W. Maza, Centro de Predicción Climática, com. pers.).

\section{Muestreo y análisis de datos}

Todas las unidades muestrales consistieron en las mismas rocas graníticas uasadas para la construcción de la escollera. Fueron extraídas originalmente de Cerro Dragón, Provincia del Chubut $\left(45^{\circ} 35^{\prime} \mathrm{S}, 6^{\circ} 04^{\prime} \mathrm{W}\right)$. Todos los sustratos 


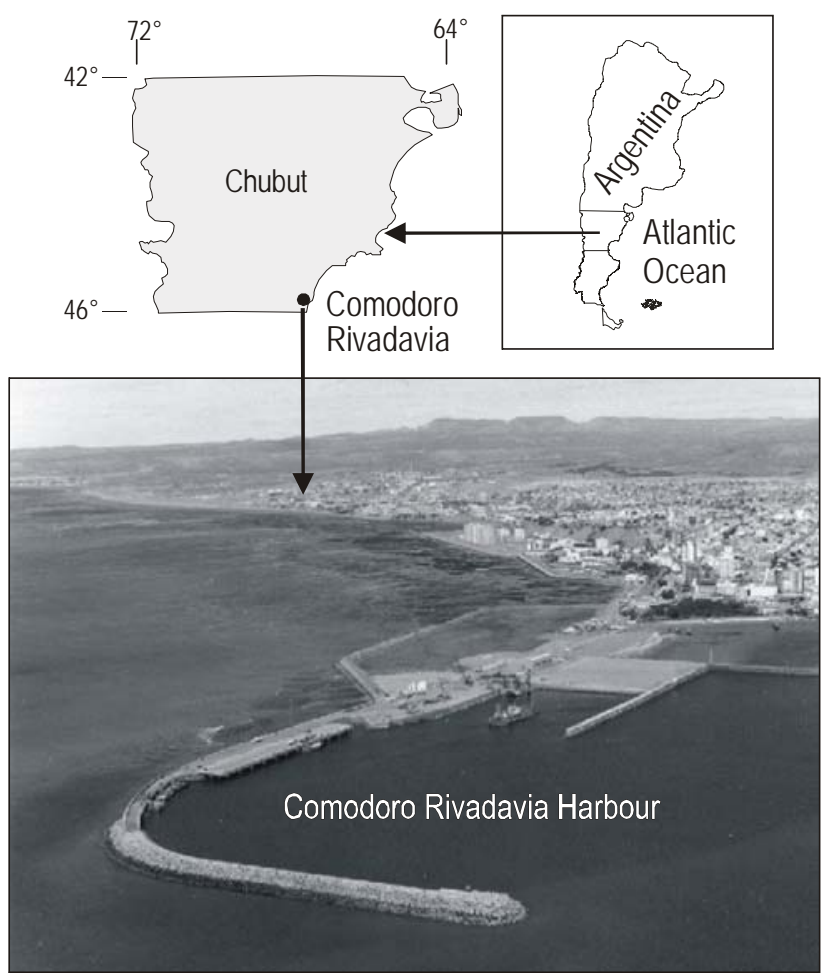

Figure 1. Study area. Arrows show the location of transects along the breakwater of Comodoro Rivadavia Harbor (Argentina).

Figura 1. Área de estudio. Las flechas señalan la ubicación de los transeptos en la escollera del puerto de Comodoro Rivadavia (Argentina).

substratum with epoxy putty. They were distributed along four transects perpendicular to the breakwater, separated by around $20 \mathrm{~m}$, at three levels: upper intertidal, middle intertidal and subtidal. Upper intertidal stones were immersed at approximately $4.50 \mathrm{~m}$ above mean low water level (MLWL). This is the most elevated zone where macroscopic marine organisms can be found and it is dominated by a belt of green algae. Middle intertidal stones were immersed at around $2.60 \mathrm{~m}$ above MLWL, in an area characterized by the presence of several invertebrates, such as the non-indigenous barnacle Balanus glandula. Stones could not be sampled in the lower intertidal level because of logistical problems. Subtidal stones were immersed at around $4 \mathrm{~m}$ below MLWL. The stones remained between 84 and 100 days in the harbor, during the following intervals: $19 / 12 / 97$ to 29/03/98 (summer), 29/03/98 to $28 / 06 / 98$ (autumn), 28/06/98 to 20/09/98 (winter) and 20/09/98 to 20/12/98 (spring). A total of 48 samples (four seasons $\times$ three levels $\times$ four replicates) were analyzed. Two additional stones were glued at each level, anticipating possible losses, but only one replicate had to be replaced (spring, subtidal) throughout the study period. Samples were fixed in $4 \%$ formalin in seawater.

Coverage of the whole benthic community was assessed within an area of $100 \mathrm{~cm}^{2}$ in the center of each stone by means of a grid of points. experimentales utilizados en este estudio estaban desprovistos de vida marina, ya que no nunca antes habían estado sumergidos. De la escollera se obtuvieron rocas de forma aproximadamente cuadrangular $(\mathrm{ca} .20 \times 20 \mathrm{~cm})$ que fueron cementadas al sustrato con masilla epóxica al comienzo de cada estación del año. Se distribuyeron a lo largo de cuatro transeptos perpendiculares a la escollera separados alrededor de $20 \mathrm{~m}$, en tres niveles: intermareal superior, intermareal medio y submareal. El intermareal superior fue muestreado aproximadamente a $4.50 \mathrm{~m}$ por sobre el nivel medio de las bajamares (NMB). Ésta es la zona más elevada en donde se encuentran organismos marinos macroscópicos y está dominada por un cinturón de algas verdes. Las rocas del intermareal medio fueron cementadas aproximadamente a $2.60 \mathrm{~m}$ por sobre el NMB, en una zona caracterizada por la presencia de varios invertebrados, tales como el cirripedio exótico Balanus glandula. No pudieron pegarse rocas en el intermareal inferior debido a problemas logísticos. Las rocas submareales fueron sumergidas aproximadamente a $4 \mathrm{~m}$ por debajo del NMB. Los sustratos permanecieron en el puerto entre 84 y 100 días durante los siguientes intervalos: 19/12/97 a 29/03/98 (verano), 29/03/98 a 28/06/98 (otoño), 28/06/98 a 20/09/98 (invierno) y 20/09/98 a 20/12/98 (primavera). Se analizó un total de 48 muestras (cuatro estaciones $\times$ tres niveles $\times$ cuatro réplicas). Se cementaron dos rocas adicionales en cada nivel, previendo posibles pérdidas, pero sólo una replica (primavera, submareal) debió reemplazarse durante todo el periodo de estudio. Las muestras fueron fijadas en formol en agua de mar al $4 \%$.

La cobertura de toda la comunidad bentónica fue estimada dentro de una superficie de $100 \mathrm{~cm}^{2}$ en el centro de cada roca mediante una malla de puntos.

Ya que los valores de cobertura no se hallaban distribuidos normalmente y las varianzas fueron con frecuencia heterogéneas debido a una alta proporción de réplicas sin ninguna especie de Ulva, se utilizó el test no paramétrico de KruskalWallis en lugar de ANOVA para poner a prueba las diferencias de cobertura en distintos niveles y estaciones (Sokal y Rohlf, 1981). En los casos en que se hallaron variaciones significativas, se llevaron a cabo comparaciones pareadas mediante pruebas de Mann-Whitney múltiples.

\section{Resultados}

Los sustratos sumergidos en la escollera fueron colonizados por cinco especies de Ulva: $U$. prolifera, $U$. intestinalis, $U$. hookeriana, $U$. compressa y $U$. linza. Su cobertura en los distintos niveles $\mathrm{y}$ estaciones se describe $\mathrm{y}$ analiza en las tablas 1 y 2.

El género mostró cambios significativos a distintos niveles: la cobertura fue significativamente mayor en el intermareal medio (tres especies) y submareal (cuatro especies) que en el intermareal superior, en donde todas las especies estuvieron ausentes. Como era de esperar, los cambios estacionales 
Since coverage values were not normally distributed and variances were frequently heterogeneous owing to a high proportion of replicates without any Ulva species, the nonparametric Kruskal-Wallis test was used instead of ANOVA to test for differences in coverage among different levels and seasons (Sokal and Rohlf, 1981). Once significant variation was indicated, multiple Mann-Whitney tests were used for pairwise comparisons.

\section{Results}

Five species of Ulva colonized the substrata immersed in the breakwater: $U$. prolifera, $U$. intestinalis, $U$. hookeriana, $U$. compressa and $U$. linza. Their coverage in the different levels and seasons is described and analyzed in tables 1 and 2 .

The genus as a whole showed significant changes at different levels: coverage was significantly higher in the middle intertidal (three species) and subtidal (four species) levels than in the upper intertidal level, where all species were absent. As expected, seasonal changes were also significant: coverage in summer (three species) and spring (three species) was higher than in autumn (one species) and winter (zero species).

Ulva prolifera showed significant changes at different levels: coverage was maximum in the middle intertidal level, even though it showed high spatial variability among replicates, and intermediate in the subtidal and absent in the upper intertidal levels. Seasonal changes were also significant, since this species showed highest coverage values in summer but was absent in winter and spring.

Ulva intestinalis showed significant seasonal changes, occurring only in spring.

Changes in coverage of $U$. hookeriana at different levels were highly significant, since this species occurred only on subtidal substrata.

Ulva compressa was recorded only in spring in the middle intertidal level, with very high spatial variability among replicates.

Ulva linza appeared just as traces on subtidal substrata during summer.

\section{Discussion}

The most abundant species of the genus Ulva in Comodoro Rivadavia Harbor were $U$. intestinalis and $U$. prolifera. The former is one of the most conspicuous and frequent algal foulers in all harbors studied to date in Argentina (e.g., Bastida et al., 1974; Brankevich et al., 1986), whereas the latter has only been recorded as a rare component of the fouling assemblages at Puerto Belgrano (Bastida et al., 1974) and the port of Mar del Plata (Bastida et al., 1980).

Ulva intestinalis and $U$. compressa are widespread in the upper intertidal zone of Buenos Aires Province (Sar et al., 1984). The latter forms a conspicuous belt at high intertidal levels of San José Gulf (Boraso de Zaixso, 1996) and is also abundant at sites impacted by eutrophication due to sewage también fueron significativos: la cobertura fue significativamente mayor en verano (tres especies) y primavera (tres especies) que en otoño (una especie) e invierno (cero especies).

Ulva prolifera mostró cambios significativos a distintos niveles: la cobertura fue máxima en el intermareal medio, aunque mostró una gran variabilidad espacial entre réplicas, intermedia en el submareal y nula en el intermareal superior. Los cambios estacionales también fueron significativos ya que esta especie presentó los valores más altos de cobertura en verano pero estuvo ausente en invierno y primavera.

Los cambios estacionales en $U$. intestinalis fueron significativos, presentándose sólo en primavera.

Los cambios en la cobertura de $U$. hookeriana a distintos niveles fueron altamente significativos, ya que esta especie se presentó sólo en sustratos submareales.

Ulva compressa fue registrada sólo en primavera en el intermareal medio, con una variabilidad espacial muy alta entre réplicas.

Durante el verano aparecieron trazas de $U$. linza en sustratos submareales.

\section{Discusión}

Ulva prolifera y $U$. intestinalis fueron las especies más abundantes del género Ulva en el puerto de Comodoro Rivadavia. Ulva intestinalis es una de las especies de algas más conspícuas y frecuentes en las incrustaciones biológicas en todos los puertos argentinos estudiados hasta el momento (Bastida et al., 1974; Brankevich et al., 1986), pero U. prolifera sólo ha sido registrada como un raro componente de las incrustaciones biológicas del puerto de Mar del Plata (Bastida et al., 1980) y Puerto Belgrano (Bastida et al., 1974).

Ulva intestinalis y $U$. compressa están ampliamente distribuidas en el intermareal superior de la Provincia de Buenos Aires (Sar et al., 1984). Esta última especie forma una conspícua cintura en el intermareal superior del Golfo San José (Boraso de Zaixso, 1996) y también es abundante en sitios impactados por eutroficación debida a descargas cloacales en las provincias argentinas de Buenos Aires (López-Gappa et al., 1993) y Chubut (Díaz et al., 2002).

La zonación vertical de algunas especies halladas en este estudio difiere de los patrones descritos previamente. Ulva hookeriana estuvo presente en el intermareal medio y superior y en pozas de marea en la zona de Comodoro Rivadavia (Rico et al., 1993), pero sólo apareció en sustratos submareales dentro del puerto. Ulva intestinalis colonizó casi exclusivamente los paneles superiores fijos a balsas experimentales fondeadas en puertos de la Provincia de Buenos Aires (Bastida et al., 1974). Sin embargo, las rocas cementadas en el intermareal superior del puerto de Comodoro Rivadavia carecían de especies de Ulva. Según Sar et al. (1984), U. intestinalis y $U$. compressa pueden dominar los niveles superiores de los sustratos rocosos o de tosca en la Provincia de Buenos Aires y su distribución vertical abarca tanto el intermareal medio como el superior. 
Table 1. Percent coverage of five species of Ulva in Comodoro Rivadavia Harbor. All species were absent in winter and from the upper intertidal level.

Tabla 1. Cobertura de las cinco especies de Ulva en el puerto de Comodoro Rivadavia. Todas las especies estuvieron ausentes en invierno y en el intermareal superior.

\begin{tabular}{lccc}
\hline Species & \multicolumn{3}{c}{ Median (minimum-maximum) } \\
\cline { 2 - 4 } & Summer & Autumn & Spring \\
\hline Ulva prolifera & & \\
Middle intertidal & $41.50(10-90)$ & $0.00(0-0)$ & $0.00(0-0)$ \\
Subtidal & $0.00(0-0)$ & $0.00(0-8)$ & $0.00(0-0)$ \\
Ulva intestinalis & & & \\
Middle intertidal & $0.00(0-0)$ & $0.00(0-0)$ & $0.00(0-1)$ \\
Subtidal & $0.00(0-0)$ & $0.00(0-0)$ & \\
Ulva hookeriana & & & $0.00(0-0)$ \\
Middle intertidal & & $0.00(0-0)$ & $0.25(0-0.5)$ \\
Subtidal & $0.00(0-0)$ & $0.00(0-0)$ & \\
Ulva compressa & $5.50(0-77)$ & & $0.00(0-95)$ \\
Middle intertidal & & $0.00(0-0)$ & $0.00(0-0)$ \\
Subtidal & $0.00(0-0)$ & $0.00(0-0)$ & $0.00(0-0)$ \\
Ulva linza & $0.00(0-0)$ & $0.00(0-0)$ & \\
Middle intertidal & & $0.00(0-0)$ & \\
Subtidal & $0.00(0-0)$ & & \\
\hline
\end{tabular}

discharges in Buenos Aires Province (López-Gappa et al., 1993) and in Chubut Province, Argentina (Díaz et al., 2002).

The vertical zonation of some of the species found in this study differs from patterns described previously. Ulva hookeriana has been found in the upper and middle intertidal zones and in tide-pools of the Comodoro Rivadavia area (Rico
Gran parte de la variación a lo largo de un gradiente de exposición al oleaje puede explicarse por las complejas interacciones entre la actividad de los herbívoros y los efectos de las variaciones en el ambiente físico que influencian el reclutamiento, la supervivencia y el crecimiento de las algas (Underwood y Jernakoff, 1984). Los resultados del presente

Table 2. Coverage of Ulva species in Comodoro Rivadavia Harbor. Results of the nonparametric Kruskal-Wallis test and multiple Mann-Whitney contrasts. $\mathrm{UI}=$ upper intertidal, $\mathrm{MI}=$ middle intertidal, $\mathrm{ST}=$ subtidal, Su = summer, Au = autumn, Wi $=$ winter, $\mathrm{Sp}=$ spring. Significant values are in bold. Pairwise tests connected with the same segment were not significant.

Tabla 2. Cobertura de Ulva en el puerto de Comodoro Rivadavia. Resultados de la prueba no paramétrica de Kruskal-Wallis $\mathrm{y}$ de los contrastes múltiples de Mann-Whitney. $\mathrm{UI}=$ intermareal superior, $\mathrm{MI}=$ intermareal medio, $\mathrm{ST}=$ submareal, $\mathrm{Su}=$ verano, $\mathrm{Au}=$ otoño, $\mathrm{Wi}=$ invierno, $\mathrm{Sp}=$ primavera. Valores significativos en negritas. Los contrastes pareados conectados con el mismo segmento no fueron significativos.

\begin{tabular}{|c|c|c|c|c|c|c|}
\hline \multirow[t]{2}{*}{ Species } & \multicolumn{4}{|c|}{ Kruskal-Wallis test } & \multicolumn{2}{|c|}{ Multiple Mann-Whitney tests } \\
\hline & Level & $P$ & Season & $P$ & Level & Season \\
\hline Ulva prolifera & 6.00 & 0.049 & 9.81 & 0.020 & MI ST UI & $\underline{\mathrm{Su} \mathrm{Au}} \mathrm{Wi} \mathrm{Sp}$ \\
\hline Ulva intestinalis & 3.80 & 0.150 & 12.79 & 0.005 & & $\underline{\mathrm{Sp}} \underline{\mathrm{Su} \mathrm{Au} W \mathrm{~W}}$ \\
\hline Ulva hookeriana & 10.89 & 0.004 & 6.13 & 0.106 & $\underline{\text { ST MI UI }}$ & \\
\hline Ulva compressa & 2.00 & 0.368 & 3.00 & 0.392 & & \\
\hline Ulva linza & 2.00 & 0.368 & 3.00 & 0.392 & & \\
\hline Total & 11.51 & 0.003 & 17.39 & 0.0005 & $\underline{\text { MI ST UI }}$ & $\underline{\mathrm{Su} S p} \underline{\mathrm{Au} \mathrm{Wi}}$ \\
\hline
\end{tabular}


et al., 1993), but only appeared on subtidal substrata within the harbor. Ulva intestinalis colonized almost exclusively the uppermost panels attached to experimental rafts moored in harbors of Buenos Aires Province (Bastida et al., 1974); however, the stones immersed in the upper intertidal level of Comodoro Rivadavia Harbor lacked all species of Ulva. According to Sar et al. (1984), $U$. intestinalis and $U$. compressa may dominate the upper levels of rocky and siltstone substrata in Buenos Aires Province, and their vertical distribution encompasses both the upper and middle intertidal zones.

Much of the variation along a gradient of wave exposure can be explained by the complex interactions between the activities of grazers and the effects of variations in the physical environment that influence the recruitment, survival and growth of algae (Underwood and Jernakoff, 1984). The present results suggest that these interactions are the most likely factors explaining differences in vertical distribution between exposed intertidal areas and habitats located within a harbor.

Seasonal changes in the coverage of Ulva in Comodoro Rivadavia Harbor were significant and matched those observed previously in other harbors of Argentina, where Ulva spp. colonized artificial panels during most of the year, but showed a minimum or were completely absent during winter (Bastida et al., 1974, 1980). As in the present study, $U$. intestinalis appeared only during spring in an intertidal community affected by a sewage outfall at Quequén (López-Gappa et al., 1993).

One of the most remarkable results of this study is the high degree of spatial variability in coverage at a scale of a few tens of meters, i.e., among replicates from the same level and season. Underwood and Chapman (1998) also found considerable small-scale patchiness among replicate quadrats within sites in intertidal assemblages from sheltered rocky shores of New South Wales, Australia.

Several life-history features of Ulva, such as high reproductive output (Boraso, 1979), high growth rates (Martins et al., 1999), significant seasonal variation in coverage and small-scale patchiness (this study), are characteristic of the well-known opportunistc strategy displayed by species of this genus, which can usually be found as discrete and ephemeral algal patches on natural and man-made hard substrata. Spatial and temporal patterns of colonization observed in this study suggest a relatively high degree of niche segregation in closely related species of the genus Ulva.

Other algae growing on the same experimental substrata showed different patterns of coverage in time and space. The stones immersed in the upper intertidal level lacked all species of Ulva, and were mainly colonized by the green algae Ulothrix flacca, Urospora penicilliformis and Blidingia minima. Coverage of Ulothrix and Urospora was highest during spring, but Blidingia reached maximum development during winter (Rico et al., 2003).

Since the presence of different Ulva species was patchy and highly seasonal, this genus does not seem to play a major role in structuring the fouling community at this harbor. trabajo sugieren que estas interacciones son los factores que más probablemente expliquen las diferencias en la distribución vertical entre las zonas intermareales expuestas y los hábitats portuarios.

Los cambios estacionales en la cobertura de Ulva en el puerto de Comodoro Rivadavia fueron significativos, y coinciden con los observados previamente en otros puertos de Argentina en donde Ulva spp. colonizó paneles artificiales durante la mayor parte del año, pero presentó un mínimo o estuvo totalmente ausente durante el invierno (Bastida et al., 1974, 1980). Al igual que en el presente estudio, $U$. intestinalis apareció sólo durante la primavera en una comunidad intermareal afectada por el vertido de efluentes cloacales en Quequén (López-Gappa et al., 1993).

Uno de los resultados más notables de este trabajo es el alto grado de variabilidad espacial en la cobertura a una escala de decenas de metros, es decir, entre replicaciones pertenecientes al mismo nivel y estación del año. Underwood y Chapman (1998) también hallaron considerable heterogeneidad entre réplicas ubicadas dentro de un mismo sitio en asociaciones intermareales de costas rocosas protegidas en Nueva Gales del Sur, Australia.

Varias características de la historia de vida de Ulva, tales como las altas tasas de reproducción (Boraso, 1979) y de crecimiento (Martins et al., 1999), y las variaciones estacionales significativas en la cobertura y heterogeneidad espacial a pequeña escala (este trabajo), son típicas de la bien conocida estrategia oportunista exhibida por las especies de este género, que suelen formar parches discretos y efímeros sobre sustratos naturales y artificiales. Los patrones espaciales y temporales de colonización observados en este estudio sugieren un grado relativamente alto de segregación de nicho en especies estrechamente emparentadas del género Ulva.

Otras algas que crecían sobre los mismos sustratos experimentales mostraron diferentes patrones temporales y espaciales de cobertura. Las piedras cementadas en el intermareal superior no presentaron ninguna especie de Ulva, sino que fueron colonizadas principalmente por las algas verdes Ulothrix flacca, Urospora penicilliformis y Blidingia minima. La cobertura de Ulothrix y Urospora fue máxima durante la primavera, pero Blidingia alcanzó su máximo desarrollo durante el invierno (Rico et al., 2003).

Ya que la presencia de distintas especies de Ulva fue discontínua y muy estacional, este género no parece cumplir un rol importante en la estructuración de las incrustaciones biológicas de este puerto.

La composición de especies y la estructura de la comunidad bentónica en Comodoro Rivadavia y otros puertos patagónicos son aún prácticamente desconocidas. Es de esperar que en este puerto relativamente remoto y aislado ocurran cambios ambientales debidos al aumento de la contaminación y el transporte marítimo, una tendencia que ya ha alterado significativamente las comunidades bentónicas costeras en el Atlántico sudoccidental (Orensanz et al., 2002). 
Species composition and benthic community structure at Comodoro Rivadavia and other Patagonian harbors still remain largely unknown. Changes in the environment due to the increase of pollution and maritime transport are expected in this relatively remote and isolated harbor, an ongoing trend that has already significantly altered coastal benthic communities in the southwestern Atlantic (Orensanz et al., 2002).

\section{Acknowledgements}

We are indebted to Horacio It for his help during the field work. Financial support from CONICET (PIP No 02126) to J. López-Gappa is gratefully acknowledged.

\section{References}

Bastida, R., Spivak, E., L’Hoste, S.G. y Adabbo, H.E. (1974). Las incrustaciones biológicas de Puerto Belgrano. I. Estudio de la fijación sobre paneles mensuales, período 1971/72. LEMIT, Anales, 3-1974: 97-165.

Bastida, R., Trivi de Mandri, M., Lichtschein de Bastida, V. and Stupak, M. (1980). Ecological aspects of marine fouling at the port of Mar del Plata (Argentina). V Congr. Int. Corrosión Mar. Incrustaciones, Gráficas Orbe, Madrid, pp. 299-320.

Boraso, A.L. (1979). Reproducción en Ulvales de Puerto Deseado (Prov. Sta. Cruz, Argentina). I. Enteromorpha. Darwiniana, 22: 241-253.

Boraso de Zaixso, A.L. (1996). Asociaciones de macroalgas intermareales en el Golfo San José (Provincia del Chubut, Argentina). Naturalia Pat., Cienc. Biol., 4: 47-64.

Brankevich, G., Flaminio, J.L. y Bastida, R. (1986). Estudios ecológicos sobre las comunidades incrustantes de la toma de agua de la central eléctrica Necochea (Puerto Quequén, Argentina), período 1981-82. CIDEPINT, Anales, 1986: 41-99.

Cardoso, P.G., Pardal, M.A., Raffaelli, D., Baeta, A. and Marques, J.C. (2004). Macroinvertebrate response to different species of macroalgal mats and the role of disturbance history. J. Exp. Mar. Biol. Ecol., 308: 207-220.

Cummins, S.P., Roberts, D.E. and Zimmerman, K.D. (2004). Effects of the green macroalga Enteromorpha intestinalis on macrobenthic and seagrass assemblages in a shallow coastal estuary. Mar. Ecol. Prog. Ser., 266: 77-87.

Díaz, P., López-Gappa, J.J. and Píriz, M.L. (2002). Symptoms of eutrophication in intertidal macroalgal assemblages of Nuevo Gulf (Patagonia, Argentina). Bot. Mar., 45: 267-273.

Dolbeth, M., Pardal, M.A., Lillebø, A.I., Azeiteiro, U. and Marques, J.C. (2003). Short- and long-term effects of eutrophication on the secondary production of an intertidal macrobenthic community. Mar. Biol., 143: 1229-1238.

Hayden, H.S., Blomster, J., Maggs, C.A., Silva, P.C., Stanhope, M.J. and Waaland, J.R. (2003). Linnaeus was right all along: Ulva and Enteromorpha are not distinct genera. Eur. J. Phycol., 38: 277-294.

\section{Agradecimientos}

Agradecemos a Horacio It por su ayuda durante el trabajo de campo y al CONICET (PIP Nº 02126) por el apoyo económico brindado a J. López-Gappa.

Traducido al español por los autores.

López-Gappa, J., Tablado, A. and Magaldi, N.H. (1993). Seasonal changes in an intertidal community affected by sewage pollution. Environ. Pollut., 82: 157-165.

Martins, I., Oliveira, J.M. and Marques, J.C. (1999). The effect of salinity on the growth rate of the macroalgae Enteromorpha intestinalis (Chlorophyta) in the Mondego estuary (west Portugal). Acta Oecol., 20: 259-265.

Orensanz, J.M., Schwindt, E., Pastorino, G., Bortolus, A., Casas, G., Darrigran, G., Elías, R., López Gappa, J., Obenat, S., Pascual, M., Penchaszadeh, P., Piriz, M.L., Scarabino, F., Spivak, E.D. and Vallarino, E.A. (2002). No longer the pristine confines of the world ocean: A survey of exotic marine species in the southwestern Atlantic. Biol. Inv., 4: 115-143.

Rascio, V. y Bastida, R. (1973). Contribución al estudio del comportamiento de las pinturas antiincrustantes. V. Acción de los tóxicos sobre algas a nivel de línea de flotación. Corr. Prot., 4: 19-27.

Rico, A., Pérez, L. y Perales, S. (1993). Especies del género Enteromorpha (Chlorophyta) en los alrededores de Comodoro Rivadavia, Chubut (Argentina). Naturalia Pat., Cienc. Biol., 1: 103-107.

Rico, A., Lanas, P. and López-Gappa, J. (2003). Colonization of Ulothrix flacca, Urospora penicilliformis and Blidingia minima (Chlorophyta) in Comodoro Rivadavia harbor (Chubut, Argentina). Rev. Mus. Arg. Cienc. Nat., n.s., 5: 93-97.

Romano, C., Widdows, J., Brinsley, M.D. and Staff, F.J. (2003). Impact of Enteromorpha intestinalis mats on near-bed currents and sediment dynamics: Flume studies. Mar. Ecol. Prog. Ser., 256: 63-74.

Sar, E., Pascual, M. y Parma, A. (1984). Consideraciones ecológicas sobre las algas del litoral rocoso bonaerense. Rev. Mus. La Plata (N.S.), Secc. Bot., 13: 143-147.

Servicio de Hidrografía Naval (1998). Tabla de Mareas, República Argentina. Puertos de la República Argentina y algunos puertos de Brasil, Uruguay y Chile, 553 pp.

Sokal, R.R. and Rohlf, F.J. (1981). Biometry. 2nd ed. W.H. Freeman, New York, 859 pp.

Underwood, A.J. and Jernakoff, P. (1984). The effects of tidal height, wave-exposure, seasonality and rock-pools on grazing and the distribution of intertidal macroalgae in New South Wales. J. Exp. Mar. Biol. Ecol., 75: 71-96.

Underwood, A.J. and Chapman, M.G. (1998). Spatial analyses of intertidal assemblages on sheltered rocky shores. Aust. J. Ecol., 23: $138-157$. 